\title{
ANALISIS KELAYAKAN BUKU AJAR KELAS 5 SD/MI TEMA 7 PERISTIWA DALAM KEHIDUPAN
}

\author{
Ramadhan Putra Pratama1', Rokhmaniyah², Ratna Hidayah ${ }^{3}$ \\ Universitas Sebelas Maret \\ ramadhanputra67@gmail.com
}

\section{Article History}

accepted 1/11/2021

approved 1/12/2021

published 31/12/2021

\begin{abstract}
The purpose of this study was to analyze the feasibility of the fifth grade textbook, theme 7, "Events in Life". This study uses a qualitative-descriptive method approach. The object of this research is the Class V Textbook Theme 7 "Events in Life" and the subjects of this research are the teachers and students of Class V at SD Negeri 1 Purwantoro, SD Negeri 2 Bangsri, MI Al Barokah in Purwantoro District. The results of the research conducted, it is known that: (1) The feasibility aspect of the content in the fifth grade textbook theme 7 "Events in Life" is feasible to use, supported by a feasibility percentage of $100 \%$ on the material completeness indicator, $100 \%$ on the material depth indicator, $100 \%$ on indicators of the accuracy of the selection of discourse, text, images and illustrations, $97.53 \%$ on indicators of conformity of concepts and material descriptions with scientific systematics, $95.06 \%$ on indicators of sample selection; (2) Aspects of the feasibility of language and the readability of books in the fifth grade textbook of theme 7 "Events in Life" are suitable for use supported by a feasibility percentage of $100 \%$ on the language suitability indicator, $100 \%$ on the suitability indicator for the book content layout element, $100 \%$ on the suitability supporting elements, $100 \%$ on the letter suitability indicator.
\end{abstract}

Keywords: Eligibility, Textbook, Fifth Grade

\section{Abstrak}

Tujuan penelitian ini adalah menganalisis kelayakan buku ajar kelas $\vee$ tema 7 "Peristiwa dalam Kehidupan". Penelitian ini menggunakan pendekatan metode kualitatif-deskriptif. Objek penelitian ini adalah Buku Ajar Kelas V Tema 7 "Perisiwa dalam Kehidupan" dan subjek penelitian ini adalah guru dan siswa Kelas $V$ pada SD Negeri 1 Purwantoro, SD Negeri 2 Bangsri, MI Al Barokah di Kecamatan Purwantoro. Hasil dari penelitian yang dilakukan, diketahui bahwa: (1) Aspek kelayakan isi pada buku ajar kelas $\mathrm{V}$ tema 7 "Peristiwa dalam Kehidupan" layak untuk digunakan didukung dengan persentase kelayakan sebesar $100 \%$ pada indikator kelengkapan materi, $100 \%$ pada indikator kedalaman materi, $100 \%$ pada indikator keakuratan pemilihan wacana, teks, gambar dan ilustrasi, $97,53 \%$ pada indikator kesesuaian konsep dan uraian materi dengan sistematika keilmuan, $95,06 \%$ pada indikator pemilihan contoh; (2) Aspek kelayakan bahasa serta keterbacaan buku pada buku ajar kelas $\mathrm{V}$ tema 7 "Peristiwa dalam Kehidupan" layak digunakan didukung dengan persentase kelayakan sebesar $100 \%$ pada indikator kesesuaian bahasa, $100 \%$ pada indikator kesesuaian unsur tata letak konten buku, $100 \%$ pada kesesuaian unsur pendukung, $100 \%$ pada indikator kesesuaian huruf. Kata kunci: Kelayakan, Buku Ajar, Kelas V 


\section{PENDAHULUAN}

Pengertian dari kurikulum berdasarkan pernyataan Nisa (2013) kurikulum diartikan sebuah program di dalam pendidikan yang memiliki isi bermacam bahan ajar serta pengalaman belajar yang telah terprogram, terencana, terancang dengan sistematis berdasarkan norma yang dilaksanakan dalam kehidupan sosial yang telah menjadi sebagai dasar dalam pemrosesan kegiatan belajar mengajar teruntuk pekerja kependidikan serta peserta didik dalam tujuan untuk pencapaian tujuan dari pendidikan. Untuk dapat melaksanakan kurikulum dibutuhkannya sarana, salah satu sarana tersebut adalah buku. Buku ajar dapat diartikan menurut Fauziyah (2016) yang mengutip dari Andi Prastowo adalah teks yang disusun secara sistematis yang menampilkan sosok utuh dari kompetensi yang akan dikuasai siswa dan digunakan dalam proses pembelajaran dengan tujuan untuk perencanaan dan penelaah implementasi pembelajaran.

Seiring perjalanan waktu, kurikulum mengalami perubahan. Dengan adanya perubahan kurikulum memiliki dampak terjadinya perubahan isi buku. Dengan perubahan isi konten dari buku tersebut belum tentu layak sehingga kelayakan buku perlu dianalisis. Dengan perubahan isi konten tersebut, hal yang menjadi pokok dari penilaian kelayakan isi atau konten berdasarkan Aulia (2015) yang mengutip dari Muslich meliputi: 1) Kesesuaian uraian materi dengan SK dan KD; 2) Keakuratan materi; 3) Materi pendukung pembelajaran.

Berdasarkan penelitian yang dilakukan oleh Lestari (2018) menunjukkan bahwa isi buku guru dan isi buku siswa memiliki tingkat kesesuaian $100 \%$ berdasarkan $\mathrm{KI}$ dan KD; dan isi buku guru serta isi buku siswa memiliki kesesuaian senilai $92,5 \%$ pada matematika, 100\% pada PPKn, 93,63\% pada Bahasa Indonesia, 100\% pada PJOK, dan $100 \%$ pada SBdP ditinjau dari cakupan dan kedalaman materi. Juga, Sekarinasih (2018) yang berjudul "Kesesuaian Materi IPA dalam Buku Ajar Tematik Edisi Revisi 2019 Kelas IV SD/MI dengan Standar Isi Kurikulum 2013" menemukan bahwa terdapat empat materi yang tak tersampaikan dan dua materi tambahan yang tidak tercantum di dalam lingkup materi yang ditentukan, penulisan kompetensi dasar buku guru tidak sesuai yang didapatkan dari sembilan ruang lingkup materi kelas IV.

Dengan demikian, rumusan masalah yang dapat dibuat untuk penelitian ini adalah "Bagaimana kelayakan buku ajar kelas 5 tema Peristiwa dalam Kehidupan yang secara khusus dilihat dari kelayakan isi dan kelayakan bahasa serta keterbacaan buku?" Penelitian ini bertujuan untuk menganalisis kelayakan isi dan kelayakan bahasa serta keterbacaan buku pada buku ajar kelas V tema 7 "Peristiwa dalam Kehidupan."

Al-Farisi (2014) buku ajar didefinisikan sebagai buku mata pelajaran tertentu yang dikategorikan sebagai buku standar dan tersusun oleh pakarnya. Menurut Esti (2012) mengutip dari Muslich, buku teks terdefinisi sebagai buku pegangan siswa berjenjang tertentu dalam bentuk media pembelajaran yang berkaitan bidang studi tertentu. Menurut Saing (2017) yang mengutip dari Suhardjono mendefinisikan buku ajar sebagai buku dipergunakan sebagai buku pelajaran di dalam bidang studi tertentu, yang termasuk buku standar yang tersusun oleh pakarnya untuk melaksanakan tujuan instruksional, terstruktur dengan sarana pengajaran di sekolah dan perguruan tinggi.

Badan Standar Nasional Pendidikan (Hendrawanto, 2017) mengatakan bahwa buku ajar yang berkualitas wajib memenuhi empat aspek kelayakan, yaitu: kelayakan isi, kelayakan penyajian, kelayakan kebahasan, dan kelayakan kegrafikan. Empat aspek tersebut akan disederhanakan menjadi:

1) Kelayakan Isi

Aspek Kelayakan isi yang meliputi:
a. Kelengkapan materi
b. Kedalaman materi
c. Keakuratan pemilihan wacana, teks, gambar dan ilustrasi
d. Kesesuaian konsep dan uraian materi dengan sistematika keilmuan 
e. Pemilihan contoh.

2) Kelayakan Bahasa dan Keterbacaan Buku

Aspek kelayakan bahasa dan keterbacaan buku yang meliputi:

a. Kesesuaian bahasa

b. Kesesuaian unsur tata letak

c. Kesesuaian unsur pendukung

d. Kesesuaian huruf buku.

METODE

Penelitian dilaksanakan pada bulan Agustus 2020 sampai dengan Juli 2021. Penelitian dilakukan di SD Negeri 1 Purwantoro, SD Negeri 2 Bangsri, dan MI Al Barokah pada Kecamatan Purwantoro. Penelitian akan menggunakan pendekatan metode kualitatif-deskriptif. Objek penelitian ini adalah buku ajar kelas $\mathrm{V}$ tema 7 "Peristiwa dalam Kehidupan". Subjek penelitian ini adalah Guru Kelas V dan Siswa Kelas V. Prosedur penelitian adalah: (1) Mengumpulkan data dan infomasi untuk memilih sekolah dan membuat instrumen penelitian mengenai kelayakan buku untuk subjek penelitian; (2) Mewawancarai guru dan siswa untuk menganalisis kelayakan buku ajar; (3) Menganalisis data yang didapatkan dan membuat narasi deskriptif; (4) Membuat kesimpulan berdasarkan data yang didapatkan. Instrumen penelitian yang digunakan adalah lembar observasi yang digunakan untuk mewawancarai guru dan siswa sekolah dasar. Aspek yang ditinjau adalah aspek kelayakan isi dan aspek kelayakan bahasa serta keterbacaan buku. Pada aspek kelayakan isi, indikator yang ditinjau adalah: (1) Kelengkapan materi, (2) Kedalaman materi; (3) Keakuratan pemilihan wacana, teks, gambar dan ilustrasi; (4) Kesesuaian konsep dan uraian materi dengan sistematika keilmuan; (5) Keakuratan pemilihan Contoh. Pada aspek bahasa dan keterbacaan buku, indikator yang digunakan adalah: (1) Kesesuaian Bahasa; (2) Kesesuaian unsur tata letak konten buku; (3) Kesesuaian unsur pendukung; (4) Kesesuaian huruf yang digunakan.

\section{Aspek Kelayakan Isi}

\section{HASIL DAN PEMBAHASAN}

Materi dari sebuah pembelajaran termasuk kedalam komponen penting dari sebuah buku ajar, dengan demikian harus dipersiapkan dengan matang dan sesuai dengan kompetensi harus dicapai oleh peserta didik. Aspek kelayakan isi meliputi: (1) Butir kelengkapan materi; (2) Butir kedalaman materi; (3) Butir keakuratan pemilihan wacana, teks, gambar dan ilustrasi; (4) Butir kesesuaian konsep dan uraian materi dengan sistematika keilmuan; (5) butir pemilihan contoh.

Berdasarkan penelitian yang dilakukan pada buku ajar kelas $\mathrm{V}$ tema 7 "Peristiwa dalam Kehidupan" dapat dinyatakan layak, didukung dengan penemuan pada indikator kelengkapan materi memiliki kelayakan sebesar $100 \%$, pada indikator kedalaman materi memiliki kelayakan sebesar 100\%, pada indikator keakuratan pemilihan wacana, teks, gambar, dan ilustrasi memiliki kelayakan sebesar $100 \%$, pada indikator kesesuaian konsep dan uraian materi dengan sistematika keilmuan memiliki kelayakan sebesar $97,53 \%$, dan pada indikator pemilihan contoh memiliki kelayakan sebesar 95,06\% 


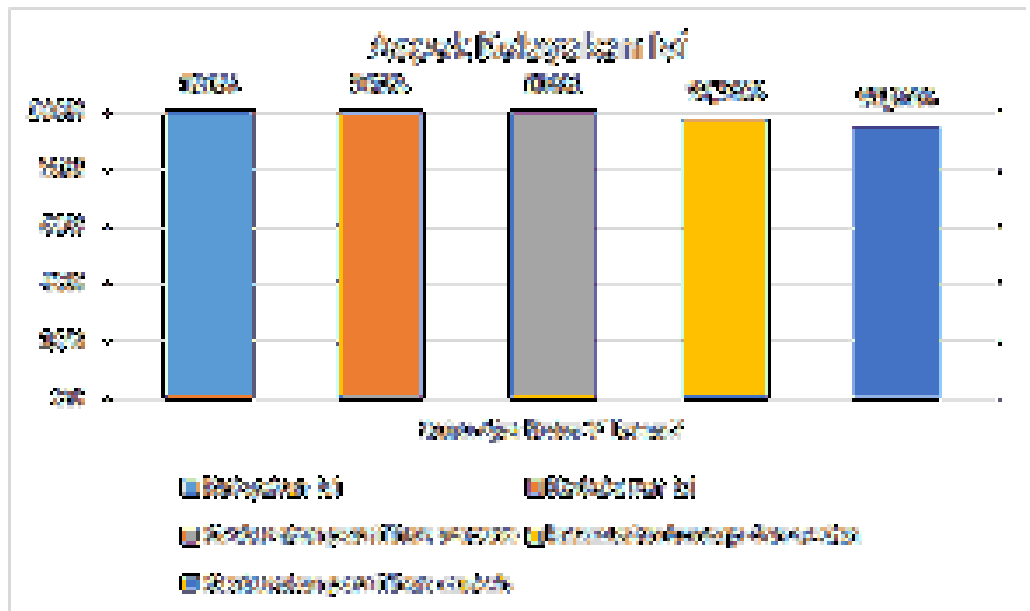

Grafik 1. Persentase Kelayakan Aspek Kelayakan Isi

Berdasarkan hasil analisis, pada buku ajar tema 7 "Peristiwa dalam Kehidupan" memiliki persentase yang kurang pada indikator kesesuaian konsep dan uraian materi dengan sistematika keilmuan dan pada indikator pemilihan contoh. Berdasarkan wawancara dengan guru pada kelas $\mathrm{V}$, hal ini disebabkan karena siswa kurang memahami konsep multikultural dilingkungannya. Hal ini dibahas pada Al Arifin (2012) yang dimana pendidikan multikultural pada pendidikan di Indonesia masih sebatas wacana. Hal ini disebabkan karena penyelenggaraan pendidikan di Indonesia dilatarbelakangi oleh primordialisme. Misalnya pendirian lembaga pendidikan berdasar latar belakang agama, daerah, perorangan maupun kelompok. Noor (2016) mengatakan bahwa faktor penyebab terjadinya fenomena primordialisme di indonesia disebabkan oleh: (1) Masih berlangsungnya interpretasi yang kurang tepat akan hakikat keindonesiaan; (2) Hadirnya formalisasi agama yang terekspresikan dalam bentuk aktivitas dan pemikiran religius yang tidak diarahkan pada penguatan keindonesiaan; (3) Hadirnya sebuah negara yang memonopoli simbol-simbil kebangsaan atas nama kesatuan geografis, modernitas, dan industrialisasi; (4) Berlangsungnya disparitas dan ketidakadilan ekonomi; (5) Perubahan institusional pemerintahan; (6) Ketimpangan keterwakilan politik dan budaya. Berdasarkan Al Arifin (2012: 79-80) praktik pendidikan multikultural di Indonesia dapat dilaksanakan secara fleksibel dengan mengutamakan prinsip-prinsip multikultural. Disebutkan tujuan umum pendidikan multikultural, adalah: (1) Mengembangkan pemahaman yang mendasarkan tentang proses menciptakan sistem dan menyediakan pelayan pendidikan yang setara; (2) Menghubungkan kurikulum dengan karakter guru, pedagogi, iklim kelas, budaya sekolah, dan konteks lingkungan sekolah guna membangun suatu visi "lingkungan sekolah yang setara". Prinsip fleksibilitas pendidikan multikultural yang disarankan oleh Gay pada Al Arifin (2012) pendidikan multikultural tidak perlu dilaksanakan dalam bentuk mata pelajaran yang terpisah, namun pendidikan multikultural diperlakukan sebagai pendekatan untuk memajukan pendidkan secara utuh dan menyeluruh. Berdasarkan zamroni pada Al Arifin (2012) pendidikan multikultural diusulkan untuk dapat dijadikan instrumen rekayasa sosial lewat pendidikan formal, artinya institusi sekolah harus berperan dalam menanamkan kesadaran hidup dalam masyarakat multikultural dan mengembangkan sikap tenggang rasa dan toleransi untuk mewujudkan kebutuhan serta kemampuan bekerjasama dengan segala perbedaan yang ada. Pada indikator pemilihan contoh, disebabkan oleh contoh yang kurang relevan dengan kehidupan siswa. Berdasarkan BSNP pada Waluyo (2021), kriteria contoh yang digunakan tidak bersifat lokal kedaerahan. Akibat kriteria tersebut, ada beberapa contoh soal yang membingungkan siswa dikarenakan siswa kurang mampu menangkap maksud dari contoh yang digunakan. 


\section{Aspek Kelayakan Bahasa serta Keterbacaan Buku}

Bahasa memiliki peran sebagai sarana untuk pemrosesan penyerapan materi oleh pengguna. Bahasa digunakan sebagai media untuk mengomunikasikan ide dan konsep dari buku kepada pembaca. Aspek kelayakan bahasa serta keterbacaan buku dikembangkan menjadi: (1) Kesesuaian bahasa; (2) Kesesuaian unsur tata letak; (3) Kesesuaian unsur pendukung; (4) Kesesuaian huruf buku.

Berdasarkan penelitian yang dilakukan dalam materi buku ajar tema 7 "Peristiwa dalam Kehidupan" sudah sesuai dengan aspek ini. Hal ini dapat terlihat dari hasil analisis dari keempat indikator pada aspek kelayakan bahasa serta keterbacaan buku dimana pada buku ajar tema 7 "Peristiwa dalam Kehidupan" memiliki persentase, yakni: $100 \%$ pada indikator kesesuaian bahasa, 100\% pada indikator kesesuaian unsur tata letak konten buku, $100 \%$ pada kesesuaian unsur pendukung, dan $100 \%$ pada indikator kesesuaian huruf yang digunakan. Berdasarkan hasil analisis, pada buku ajar tema 7 "Peristiwa dalam Kehidupan" memiliki persentase yang tinggi pada aspek kesesuaian bahasa serta keterbacaan buku.

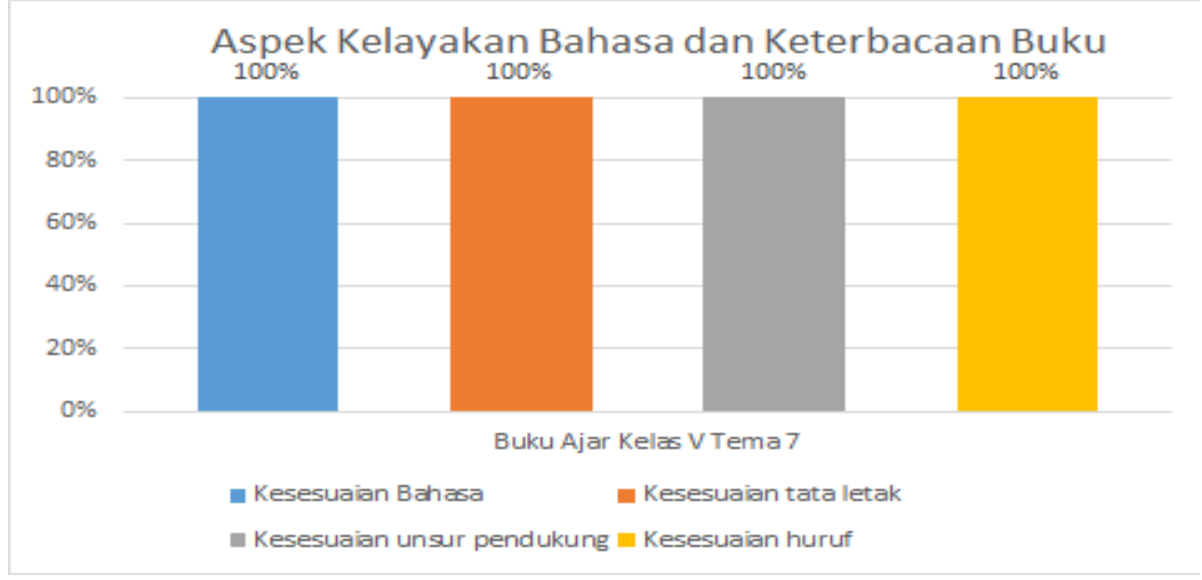

Grafik 2. Persentase Kelayakan Aspek Kelayakan Bahasa dan Keterbacaan

Berdasarkan Purnanto dan Mustadi (2016), kelayakan penggunaan bahasa dapat ditinjau melalui: (1) Kelugasan; (2) Keefektifan kalimat; (3) Ketepatan kata; (4) Kebakuan istilah; (5) Komunikatif; (6) Dialogis dan Interaktif; (7) Kemampuan memotivasi peserta didik; (8) Kesesuaian dengan Kaidah Bahasa Depdiknas; (9) Penggunaan istilah, simbol, dan ikon penggunaan. Hasil penelitian pada Hesti (2016) bahwa kelayakan bahasa pada buku mata pelajaran IPS Kelas III di SD Negeri Rawamangun 05 Jakarta Timur terbitan Erlangga pada tahun pelajaran 2015-2016 memiliki aspek kesesuaian dengan tingkat perkembangan peserta didik, komunikatif, keruntutan dan kesatuan gagasan dapat dikategorikan baik secara keseluruhan telah mencapai skor 92,85\%. Didukung juga oleh, penelitian dari Listriani (2020) dimana aspek kelayakan kebahasaan, secara umum sudah sesuai dengan tingkat perkembangan peserta didik, bersifat komunikatif, dan beruntut.

\section{SIMPULAN} adalah:

Berdasarkan hasil penelitian dan pembahasan, simpulan yang dapat dibuat

1. Aspek kelayakan isi pada buku ajar kelas $\mathrm{V}$ tema 7 sudah layak untuk digunakan didukung dengan persentase kesesuaian pada indikator kelengkapan materi sebesar $100 \%$, pada indikator sebesar $100 \%$, pada indikator keakuratan pemilihan wacana, teks, gambar, dan ilustrasi sebesar $100 \%$, pada indikator kesesuaian 
konsep dan uraian materi sebesar $97,53 \%$, dan pada indikator pemilihan contoh sebesar $95,06 \%$

2. Aspek kelayakan bahasa serta keterbacaan buku pada buku ajar kelas $\mathrm{V}$ sudah layak untuk digunakan didukung dengan persentase kesesuaian pada indikator kesesuaian bahasa sebesar $100 \%$, pada indikator kesesuaian unsur tata letak sebesar $100 \%$, pada indikator kesesuaian unsur tata letak konten buku sebesar $100 \%$, dan pada indikator kesesuaian huruf yang digunakan sebesar $100 \%$

Berdasarkan simpulan yang diambil, implikasi yang dapat dibuat adalah buku ajar kelas $\mathrm{V}$ tema 7 "Peristiwa dalam Kehidupan" layak untuk digunakan.

Saran yang dapat dibuat berdasarkan simpulan dan implikasi, adalah:

1. Teruntuk penulis dan penerbit buku, untuk mengembangkan buku yang ditulis dan diterbitkan supaya aspek kelayakan pada buku selalu berkembang dan memadai untuk dipergunakan dalam pembelajaran.

2. Teruntuk peneliti lainnya, agar dapat dijadikan referensi penelitian analisis kelayakan buku ajar terutama pada Sekolah Dasar atau Madrasah Ibtidaiah.

\section{DAFTAR PUSTAKA}

Al Arifin, A. H. (2012). Implementasi Pendidikan Multikultural dalam Praksis Pendidikan di Indonesia. 2012. Vol. 1 No.1, Juni, 2012. Diperoleh dari https://journal.uny.ac.id/index.php/jppfa/article/view/1052 pada 03 Juli 2021

Al Farisi, A. F. (2014). Pengaruh Buku Ajar Al-Islam Terhadap Prestasi Belajar PAl Siswa Kelas VIII Di SMP Muhammadiyah 5 Surabaya. Jurnal UIN Sunan Ampel Surabaya. Diperoleh pada 30 Agustus 2020 dari http://digilib.uinsby.ac.id/1471/

Aulia, A. R. (2015). Analisis Konten Buku Ajar Fisikan Kelas X Kurikulum 2013 Materi Elasitisitas. Jurnal Universitas Sebelas Maret. Diperoleh pada 23 Desember 2020 dari https://digilib.uns.ac.id/dokumen/detail/49278/Analisis-Konten-Buku-Ajar-FisikaKelas-X-Kurikulum-2013-Materi-Elastisitas

Esti, P. (2012). Keterbacaan Wacana Dalam Buku Teks Marsudi Basa Lan Sastra Jawa Anyar Kelas VIII Untuk Pembelajaran Bahasa Jawa Sekolah Menengah Pertama. Jurnal Universitas Negeri Yogyakarta. Diperoleh pada 30 Agustus 202 dari https://eprints.uny.ac.id/9231/

Hendrawanto, Y. (2017). Kelayakan Buku Teks Bahasa Indonesia SMA/SMK: Analisis Kebahasaan, Isi, Penyajian, Kegrafikan, dan Keterbacaan. Jurnsal UNNES. Diperoleh pada 15 Februari 2021 dari https://lib.unnes.ac.id/27037/

Hesti Mailindri. HB,. (2016). Analisi Kualitas Buku Mata Pelajaran IPS Kelas II SD Negeri Rawamangun 05 Jakarta Timur. Jurnal Universitas Negeri Jakarta. Diperoleh pada 04 Juli 2020 dari http://repository.unj.ac.id/1224/

Lestari, S. P. (2018). Konsep Belajar dalam Alquran Surah Al Baqarah Ayat 31-33. Jurnal Universitas Islam Negeri Sumatera Utara. Diperoleh pada 14 Januari 2021 dari http://repository.uinsu.ac.id/4729/

Listriani (2020). Analisis Kelayakan Buku Teks Kurikulum 2013 Sekolah Dasar/ Madrasah Ibtidaiyah Kelas II Semester II Tema Bermain di Lingkunganku. Jurnal Institut Agama Islam Negeri Purwokerto. Diperoleh pada 03 Juli 2020 dari http://repository.iainpurwokerto.ac.id/6925/

Noor, F. (2006). Nasionalisme, Demokratisasi, dan Sentimen Primordialisme di Indonesia: Problematika Identitas Keetnisan Versus Keindonesiaan (Studi Kasus Aceh, Papua, Bali, dan Riau). 2016. Vol. 5, No 1. Diperoleh pada 21 Juli 2021 dari https://ejournal.politik.lipi.go.id/index.php/jpp/article/view/505/314 
Purnanto, A. W., Mustadi, A. (2016). Analisis Kelayakan Bahasa Dalam Buku Teks Tema 1 Kelas I Sekolah Dasar Kurikulum 2013. 2016. Vol. 3 No. 3. Diperoleh pada 21 Juli 2021 dari http://journals.ums.ac.id/index.php/ppd/article/view/2773

Santoso, N. P. (2015) Analisis Kesessuaian Buku Teks Pelajaran Bahasa Indonesia dengan Kurikulum 2013 Sekolah Menengah Atas Kelas XI Semester 1. Jurnal Universitas Sebelas Maret. Diperoleh pada 15 Februari 2021 dari https://digilib.uns.ac.id/dokumen/detail/45410/Analisis-Kesesuaian-Buku-TeksPelajaran-Bahasa-Indonesia-dengan-Kurikulum-2013-Sekolah-Menengah-AtasKelas-XI-Semester-1.

Sekarinansih, A. (2018). Kesesuaian Materi IPA Dalam Buku Ajar Tematik Edisi Revisi 2017 Kelas IV SD/MI Dengan Standar Isi Kurikulum 2013. Jurnal IImu Pendidkan: Jurnal IImiah PGMI, 4(1), 56-67. Diperoleh pada 16 September 2020 dari http://jurnal.radenfatah.ac.id/index.php/jip/article/view/2266 